\title{
PENGARUH VARIASI PENGOLAHAN DAUN DAN BUAH KACANG PANJANG TERHADAP KADAR LOGAM BERAT Pb DAN Cd SERTA SOSIALISASI PENANGANAN SAYURAN TERCEMAR SEBAGAI SUMBER BELAJAR
}

\section{Tantya Pramudita}

\author{
SMP PGRI 1 Trimurjo Lampung Tengah \\ Email:pramtantya22@g mail.com
}

\begin{abstract}
Long bean plants are annual shrubs in the form of compound leaves. Long beans are long and slender pods. Pod length is around 10-80 cm. Learning media innovation in the form of posters that are in line with its function, namely as an independent teaching material, substitute educator functions, as an evaluation tool and as reference material in the community. The research was included in the type of descriptive-quantitative research using Complete Random Design (CRD) method and the research method used was purposive sampling method. The population of this study was long bean leaves and fruit with washing treatment, namely: 0 seconds control (not washed), one to three times with 5 seconds, 10 seconds, and 15 seconds by immersion, and cooking, namely: control, steamed, boiled, and sauteed. Learning resources made from this study in the form of posters were validated by linguists with a level of validity $80.5 \%$, design experts $80 \%$ and biology teachers represented housewives $83.3 \%$, obtained an average score of $81.3 \%$ showing posters can be used with good criteria.
\end{abstract}

Kata Kunci: kacang panjang, pengolahan, pencucian, pemasakan, logam berat $\mathrm{Cb}$ dan $\mathrm{Cd}$, poster

\section{PENDAHULUAN}

Biologi merupakan ilmu yang mempelajari mahkluk hidup baik hewan, tumbuhan dan manusia yang menggunakan pendekatan scientific approach, inidimaksudkan untuk memberikan pemahaman kepada siswa dalam mengenal, memahami berbagai materi menggunakan pendekatan ilmiah, bahwa informasi bisa berasal dari mana saja, kapan saja. Pembelajaran yang menekankan pada pemberian pengalaman secara langsung baik menggunakan observasi, eksperimen maupun cara yang lainnya, sehingga realitas yang berbicara sebagai informasi atau data yang diperoleh selain valid juga dapat dipertanggungjawabkan sehingga informasi yang didapatkan akan lebih banyak dan tidak terpaku pada informasi guru (Sujarwanta, 2012).

Poster ialah media publikasi yang terdiri atas tulisan, gambar ataupun kombinasi antar keduanya dengan tujuan memberikan informasi kepada khalayak ramai. Poster biasanya dipasang ditempat-tempat umum yang dinilai strategis seperti sekolah, kantor, pasar, mall dan tempat-tempat keramaian lainnya, informasi yang ada pada poster umumnya bersifat mengajak masyarakat. Tujuan poster dalam 
pembelajaran biologi tentu bukan tanpa sebab, tetapi memiliki maksud dan tujuan sendiri. Tujuan dalam hal ini adalah untuk megetahui pengaruh pengolahan yang lebih efektif mengurangi kadar logam berat $\mathrm{Pb}$ dan Cd pada daun dan buah kacang panjang.

Kacang panjang merupakan tanaman semusim daunnya berupa daun majemuk yang tersusun atas tiga helai, lonjong, berseling, 5 panjang 6-8 $\mathrm{cm}$, lebar 3-4,5 $\mathrm{cm}$, tepi rata, pangkal membulat, ujung lancip, pertulangan menyirip, tangkai silindris, panjang kurang lebih $4 \mathrm{~cm}$, dan berwarna hijau (Hutapea, 1994).

Buah kacang panjang berbentuk polong bulat panjang dan ramping. Panjang polong sekitar $10-80 \mathrm{~cm}$. Warna polong hijau muda sampai hijau keputihan. Polong kacang biasanya dapat dipanen pertama kali umur 2-2,5 bulan. Pemanenan selanjutnya seminggu sekali dan dapat berlangsung selama 3,5-4 bulan (Haryanto, 2007).

Menurut Sudjana (1991), mengatakan pada sayuran yang dilakukan pengolahan seperti dimasak terlebih dahulu, zat gizinya akanberubah sehingga kualitas ataupun mutunya lebih rendah daripada bahan mentahnya. Ini berarti risiko untuk terkontaminasi kadar logam berat dan tertular bakteri penyakit juga lebih besar karena sayuran yang dijadikan lalapan tidak dimasak terlebih dahulu.

Fungsinya sebagai pengatur metabolisme tubuh, meningkatkan kecerdasan dan ketahanan tubuh memperlancar proses pencernaan karena kandungan seratnya yang tinggi (Bastianus dkk., 2014). Variasi pengolah daun dan buah kacang panjang di masyarakat belum banyak yang mengetahui, bagaimana cara mencuci yang baik dan tepat serta memasak bukan hanya sekedar matang tetapi kandungan gizinya tetap baik, bukan malah memakan ampas sayurannya saja tetapi dapat mengurangi logam berat $\mathrm{Pb}$ dan $\mathrm{Cd}$ pada bagian daun dan buah kacang panjang, adanya kadar logam yang menempel baik dipermukaan sayur tersebut dapat membahayakan tubuh manusia yang mengonsumsinya sehingga perlu adanya pengolahan yang tepat dalam penelitian.

Proses pencucian dan perebusan untuk mengurangi residu insektisida adalah hal yang umum dilakukan di rumah tangga karena dapat dilakukan dengan air mengalir maupun larutan pencuci yang tersedia di dapur. Semakin lama pencucian dan lama perebusan maka kadar logam berat $\mathrm{Pb}$ semakin berkurang (Wid yantari dkk., 2015).

Kadar logam berat $\mathrm{Pb}$ dan $\mathrm{Cd}$ salah satu problem utama lingkungan adalah kontaminasi logam toksik pada tanah pertanian yang mengakibatkan stres pada tanaman. Stres tanaman yang diakibatkan oleh logam toksik tiga kali lebih besar daripada yang disebabkan oleh pestisida (Jeliazko, 2001).

Dampak negatif logam berat terhadap tanaman adalah menurunkan aktivitas organisme serta menurunkan kesuburan tanah dan kandungan vitamin serta proteinnya akibatnya jumlah produksi juga akan menurun. Akibat yang paling fatal dari tercemarnya tanaman oleh logam berat adalah terkontaminasinya sistem rantai 
makanan apalagi jika dikonsumsi manusia.

Beberapa peneliti telah menyimpulkan bahwa beberapa logam berat memberikan efek negatif terhadap makhluk hidup termasuk manusia, hewan, maupun tumbuhan. Di Kota Metro sendiri belum adanya kasus mengenai kejadian yang disebabkan oleh logam berat yang dikonsumsi secara berkala, namun di aktivitas sehari-hari manusia di perkotaan tidak terlepas dari polusi udara dari asap kendaraan sehingga bukan hanya manusia saja tetapi pada hewan dan tumbuhan akan terkena dampaknya, mengkonsumsi daun dan buah kacang panjang pada manusia merupakan salah satu sumber energi vitamin, protein, dan mineral serta antioksidan yang baik bagi tubuh jika dikonsumsi dengan benar, tapi jika salah mengkonsumsinya malah akan menjadi racun bagi tubuh.

Pengaruh Cadmium (Cd) pada konsentrasi tertentu terhadap tanaman juga telah diamati oleh beberapa peneliti. Widowati, (2011) Logam berat dalam kadar rendah umumnya sudah beracun bagi tumbuhan, hewan, dan manusia. Beberapa logam berat yang sering mencemari habitat adalah $\mathrm{Hg}, \mathrm{Cr}, \mathrm{As}, \mathrm{Cd}$ dan $\mathrm{Pb}$. Pertumbuhan biji dan daun Betula pendula juga dipengaruhi oleh Cd (Gussarsson, 1994). Penelitian tersebut menunjukkan kadar logam berat Cadmium (Cd) memberikan dampak yang negatif dan merugikan tanaman itu sendiri apalagi pada manusia.

Timbal $(\mathrm{Pb})$ dapat ditemukan di alam sebagai unsur maupun senyawa. Aktivitas manusia menyebabkan konsentrasi Timbal $(\mathrm{Pb})$ dalam lingkungan meningkat. Polusi timbal dapat terjadi di tanah, air, maupun udara karena penggunaannya yang sangat luas. Timbal $(\mathrm{Pb})$ dipakai dalam jumlah besar pada pabrik baterai, pabrik logam, dan pewarna. Fardiaz (1992) mengatakan bahwa penggunaan timbal terbesar adalah pada produksi aki untuk mobil. Timbal juga banyak digunakan sebagai amunisi, pelapis kabel, pipa ,bahan kimia, dan pewarna.

Widowati, dkk.,

menyatakan Logam berat yang terdapat pada tanaman pangan juga dapat terakumulasi dalam tubuh manusia jika dikonsumsi terus menerus. Hal ini disebabkan karena tanaman kacang panjang memperoleh nutrisi dari lingkungan tempat dia tumbuh.

Pendidikan biologi perlu adanya inovasi dan kreatifitas dalam menyajikan informasi bukan hanya sekedar penyampaian informasi dipendidikan formal seperti di sekolah dan perguruan tinggi, tetapi perlu adanya informasi yang ditranfer ke masyarakatdalam keselarasan supaya manusia dan alam dapat saling menjaga keraturan, tetapi dari dulu sampai sekarang manusia banyak melakukan aktivitas sehingga menimbulkan cemaran yang dapat membahayakan bagi dirinya sendiri dan alam sekitarnya.

Di Kota Metro belum adanya informasi mengenai data pengaruh variasi pengolahan sayuran daun dan buah kacang panjang terhadap kadar logam berat $\mathrm{Pb}$ dan $\mathrm{Cd}$ serta sosialisasi penanganan sayuran tercemar, maka dari data yang diperoleh dalam penelitian akan digunakan sebagai pembuatan media belajar di masyarakat untuk mensosialisasikan perlakuan 
variasi pengolahan yang paling baik untuk mengurangi kadar logam berat $\mathrm{Pb}$ dan $\mathrm{Cd}$. Dengan penelitian ini bertujuan untuk mengetahui pengaruh variasi pengolahan daun dan buah kacang panjang terhadap kadar Timbal $(\mathrm{Pb})$ dan Cadmium (Cd). Untuk mengetahuai pengolahan yang lebih efektif mengurangi kadar logam berat Timbal $(\mathrm{Pb})$ dan Cadmium $(\mathrm{Cd})$ pada daun dan buah kacang panjang serta sosialisasi penanganan sayuran tercemar. Untuk mengetahui variasi kadar logam berat dari hasil penelitian pengolahan daun dan buah kacang panjang terhadap kadar Timbal $(\mathrm{Pb})$ dan Cadmium (Cd) sebagai sosialisasi penanganan sayuran tercemar, dan dapat memberikan pengetahuan kepada masyarakat untuk dapat melakukan pengolahan yang baik dalam penanganan sayuran tercemar. Hal ini mendorong peneliti

\section{METODE}

Penelitian menggunakan metode purposive sampling artinya menentukan pengambilan sampel dengan cara menetapkan ciri-ciri khusus sesuai dengan tujuan penelitian dengan menggunakan 2 jenis bagian sayuran kacang panjang yaitu daun dan buah kacang panjang terhadap kadar logam berat $\mathrm{Pb}$ dan $\mathrm{Cd}$ sesuai dengan penilaian peneliti (Fachrul \& Ferianita , 2007). Pengukuran akumulasi logam berat menggunakan metode Vogel's Spectrophometer UV-Vis, pengukuran dilakukan di Laboratorium Kimia Analitik Universitas Muhammadiyah Malang.

Penelitian meliputi organ daun dan buah. Langkah selanjutnya menimbang masing-masing bagian organ tanaman sebanyak 100 gram. Setelah itu dilakukan proses pengolahan yaitu yang pertama pencucian sebanyak satu kali,dua kali dan tiga kali, dan pengolahan dengan cara dimasak yaitu direbus, dikukus, dan ditumis dengan dua kali pengulangan. Pada variabel penelitian ini difokuskan pada pengolahan dengan keadaan segar tanpa dilakukan pencucian dan pemasakan dengan cara tidak diolah sebagi kontrol, dicuci selama lima detik, sepuluh detik dan lima belas detik dengan tehnik pencelupan dan mengganti air, kemudian cara dimasak dikukus, direbus, dan ditumis. Semua tanaman daun dan buah kacang panjang yang sudah dilakukan pengolahan di kemas dalam plastik kreb dengan menambahkan Natrium Benzoat kemudian proses terakhir yaitupengiriman sampel ke Laboratorium Kimia Analitik Universitas Muhammadiyah Malang untuk dilakukan analisis kadar logam beratnya.

Data hasil penelitian yang diperoleh bersumber dari data primer dan sekunder selanjutnya di analisis menggunakan aplikasi spss 21. Data primer di dapat dari data yang diperoleh dari Lab Kimia Analitik Universitas Muhammadiyah Malang, sedangkan data sekunder berasal dari wawancara warga yang menanam tanaman kacang panjang.

\section{Analisis Poster}

Penyusunan poster agar dapat dimanfaatkan maka perlu adanya pengakuan dari beberapa pihak. Pengakuan poster dilakukan dengan cara melakukan uji validasi ahli isi 
poster dan uji validasi ahli desain. Hal ini dilakukan demi memperoleh kelayakan poster sehingga dapat digunakan dalam pemberian informasi bagi masyarakat umum. Poster akan divalidasi dengan memperhatikan beberapa aspek, yaitu: identitas poster, tampilan/desain poster, bahasa/kontekstual poster, isi poster. Berdasarkan uraian diatas maka untuk menganalisis poster dapat menggunakan angket yang diberikan kepada para ahli. Validasi bahan ini menggunakan sistem angket dengan memberikan respon penilaian berupa skor pada setiap aspek, yaitu skor $1=$ sangat tidak setuju, $2=$ tidak setuju, $3=$ setuju, dan $4=$ sangat setuju (Sumardana, 2016).

$\% \quad$ Kelayakan poster
$\frac{\sum \text { skor semua aspek darisemuavalidator }}{\text { skormaksimalsemua aspek }} \times 100 \%$

\section{HASIL DAN PEMBAHASAN}

Penelitian yang telah dilaksanakan untuk menurunkan kadar logam $\mathrm{Pb}$ dan $\mathrm{Cd}$ yang dianggap sebagai bahan pencemar yang banyak terakumulasi pada media tanam dan penggunaan pupuk pestisida dalam proses penanaman sayuran, logam berat $\mathrm{Pb}$ dan $\mathrm{Cd}$ merupakan logam yang memiliki massa jenis $\geq 11,34$ $\mathrm{gr} / \mathrm{cm}^{3}$ untuk timbal $(\mathrm{Pb})$ dan 8,64 $\mathrm{g} / \mathrm{cm}^{3}$ titik leleh $321^{\circ} \mathrm{C}$, titik didih $767^{\circ} \mathrm{C}$, dengan massa jenis tersebut logam berat sulit untuk terurai di lingkungan. Adanya logam berat di lingkungan mengakibatkan lingkungan menjadi tercemar, pencemaran logam berat yang tidak terkendali, karena berat jenisnya tinggi, peluang terakumulasinya logam tersebut dalam lingkungan. Menurut Charlena (2004) menyatakan bahwa logam berat yang ada di lingkungan tanah, air dan udara dengan suatu mekanisme masuk ke dalam makhluk hidup.

- Validasi poster dilakukan oleh tim validasi ahli tampilan/desain, ahli isi materi, dan dari pihak pendidik. Bahan ajar poster yang diuji berdasarkan hasil criteria kelayakan sumber belajar yang dibuat dari penelitian ini berbentuk poster berbasis potensi lokal yang divalidasi oleh ahli kevalidan $80,5 \%$, ahli desain $80 \%$ dan guru biologi mewakili ibu rumah tangga $83,3 \%$, diperolehskor rata-rata sebesar $81,3 \%$ menunjukkan poster dapat digunakan dengan kreteria baik. dari 81 sampai 100 yang dibuat sebagai bahan ajar poster dapat digunakan dengan kreteria baik.

Berdasarkan hasil penelitian yang telah dilakukan pada tanaman sayur salah satunya kacang panjang merupakan sumber protein dan vitamin yang sangat penting bagi tubuh manusia pada bagian daun dan buah. Saat ini tanaman sayur mengalami perhatian karena penggunaan pupuk atau pestisida kimia. Lamanya pemajanan antara logam berat dan tanaman kacang panjang membuat logam berat yang berada di media akan terserap terus oleh tanaman.hal ini dikarenakan tanaman kacang panjang melakukan proses transpirasi yang harus diimbangi dengan proses penyerapan, artinya semakin lama tanaman terpajan atau terkena oleh logam berat maka semakin banyak logam berat yang terserap yang berarti semakin lama di panen dan diberi pupuk pestisida untuk mengusir hama dan serangga maka semakin banyak 
logam berat terserap kedalam tubuh tanaman tersebut, membuat akumulasi logam berat dalam bagian tubuh tanaman juga semakin meningkat, logam berat dapat terakumulasi dalam akar, batang maupun pada daun serta lokasi penanaman yang banyak menyerap polutan mengakibatkan tanaman sayur akan berbahaya jika dikonsumsi terus menerus sebab logam akan tertimbun di organ tubuh manusia (biomagnifikasi) yang artinya sedikit demi sedikit logam itu akan tertimbun, jika sudah demikian proses biomagnifikasi yang semakin lama juga akan bahaya bagi kesehatan manusia yang mengkonsumsinya.

Salah satu upaya yang dianggap mampu mengurangi dampak dari bahaya sayuran tercemar logam adalah dengan proses pengolahan yang benar dan baik. Pengolahan yang biasa dilakukan dalam skala rumah tangga yaitu dengan cara pencucian, dikukus, direbus, dan ditumis. Tanaman sayur yang dianggap sebagai tanaman hiperakumulator adalah daun dan buah kacang panjang. Potensi tanaman yang mampu mengakumulasi dan menyerap partikel logam itulah yang dianggap penting untuk dilakukan pengolahan, agar aman dikonsumsi bagi tubuh dan dari analisis data perhitungan rata-rata serta menggunakan perhitungan spss 21 diperoleh hasil.

\section{Pengaruh Berbagai Variasi Pengolahan pencucian terhadap Kadar Logam Berat Timbal (Pb) dan Cadmium (Cd) pada daun dan buah Kacang Panjang}

Berdasarkan ketiga uji yang telah dilakukan mulai dari uji normalitas, uji homogenitas dan uji hipotesis dengan uji analisis variansi (ANAVA) dua arah, menunjukkan hasil menolak Ho yang artinya terdapat perbedaan rata-rata kadar logam berat timbal $(\mathrm{Pb})$ dan Cadmium (Cd) pada berbagai variasi pengolahan. Berdasarkan hasil penelitian dapat dilihat bahwa setiap pengolahan dapat menurunkan kadar logam, walapun perbedaan yang terlihat hanya sedikit tetapi dapat dijadikan acuan bahwa variasi pengolahan yang berbeda dapat menghasilkan penurunan kadar logam yang berbeda pula. Berdasarkan hasil output di atas, terlihat nilai signifikansinya $0,027<0,05$, yang berarti nilai signifikansinya lebih kecil dari $\alpha=0,05 \quad$ sehingga $\mathrm{H}_{0}$ ditolak artinya ada perbedaan rata-rata kadar $\mathrm{Pb}$ dan $\mathrm{Cd}$ pada variasi pencucian ini berarti variasi pengolahan yang dapat menurunkan kadar logam paling tinggi pada daun kacang dan daun adalah dengan cara pencucian sebanyak 3 kali selama 15 detik.

2. Pengaruh Berbagai Variasi Pengolahan pemasakan terhadap Kadar Logam Berat Timbal (Pb) dan Cadmium (Cd) pada daun dan buah Kacang Panjang.

Adanya Pengaruh Berbagai Variasi Pengolahan pencucian dan pemasakan terhadap Kadar Logam Berat Timbal $(\mathrm{Pb})$ dan Cadmium (Cd) pada daun dan buah Kacang Panjang disebabkan karena pada proses ditumis sayuran diolah dalam air mendidih pada suhu $\pm 100^{\circ} \mathrm{C}$ sehingga logam yang ada pada organ sayur dapat terurai keluar 
bersama uap air pada saat dikukus. Sedangkan, sayuran yang direbus dalam air mendidih pada suhu \pm $100^{\circ} \mathrm{C}$ mengakibatkan logam berat yang ada pada organ keluar dan larut bersama air yang mendidih, dan pada saat ditumis dengan sedikit minyak dapat mempermudah logam berat keluar karena adanya pemanasan langsung dengan perantara sedikit minyak pada saat menumis. Pernyataan ini diperkuat oleh pendapat Budiari dkk (2015) bahwa proses perebusan dapat memecah ikatan logam berat pada jaringan tumbuhan, suhu tinggi dapat menyebabkan senyawa pengikat logam berat pada tumbuhan melepaskan ikatannya sehingga senyawa yang terikat pada jaringan tumbuhan hijau dapat terlepas. Sedangkan sayuran yang ditumis mempunyai kadar air relatif rendah daripada sayuran yang direbus atau dikukus. Hal ini karena matrik jaringan sayuran yang semula terisi oleh air serta komponen organik lainnya akan terdegradasi, kemudian keluar dari jaringan dan digantikan oleh miselmisel minyak. Jika bahan segar ditumis, maka kulit bagian luar akan mengerut akibat proses dehidrasi. Selama proses menumis berlangsung, sebagian minyak akan masuk ke dalam bahan kemudian mengisi ruang kosong yang semula diisi air dan komponen organik lainnya (Aisyah dkk, 2015) inilah mengapa kadar logam berat dapat berkurang secara signifikan ketika ditumis dan dicuci sebanyak tiga kali dalam waktu 15 detik dibandingkan dengan data lainnya ini sesusi dengan berdasarkan hasil output di atas, terlihat nilai signifikansinya $0,027>0,05$, yang berarti nilai signifikansinya lebih kecil dari $\alpha=0,05$ sehingga $\mathrm{H}_{0}$ ditolak artinya ada perbedaan ratarata kadar $\mathrm{Pb}$ dan $\mathrm{Cd}$ pada pencucian dan pemasakan.

\section{Inte raksi Berbagai Variasi Pengolahan pencucian dan pemasakan terhadap Kadar Logam Berat Timbal (Pb) dan Cadmium (Cd) pada daun dan buah Kacang Panjang}

Berdasarkan ketiga uji yang telah dilakukan mulai dari uji normalitas, uji homogenitas dan uji hipotesis dengan uji analisis variansi (ANAVA) dua arah, menunjukkan hasil terima Ho yang artinya tidak ada perbedaan rata-rata kadar logam berat timbal $(\mathrm{Pb})$ dan Cadmium (Cd) pada daun dan buah kacang panjang. Terdapat perbedaan hasil yang ditunjukkan dari penghitungan menggunakan SPSS 21, data yang dihasilkan menunjukkan bahwa antara jenis sayuran baik itu daun kacang panjang maupun buah tidak terdapat perbedaan rata-rata kadar $\mathrm{Pb}$ dan $\mathrm{Cd}$ yang signifikan dan oleh sabab itu tidak dapat dilakukan ui lanjutan (tukey) karena diperoleh nilai signifikan 0,371 .

\section{Implementasi sebagai Sosialisasi di masyarakat}

Sumber belajar yang digunakan dalam penyusunan bahan ajar Poster yang diperoleh dari hasil dapat dipakai dalam proses belajar mengajar dalam pendidikan. Sumber belajar mempunyai peran yang sangat erat 
dengan pembelajaran yang dilakukan, dan pola-pola yang dilakukan oleh guru. Sumber belajar adalah segala sesuatu dan dengan mana seseorang dengan mempelajari sesuatu meliputi: pesan, orang, bahan, alat, teknik, dan latar (Karwono \& Mularsih, 2012). Berdasarkan penjelasan di atas, maka penelitian yang digunakan sebagai sumber belajar dalam penyusunan bahan ajar poster memfokuskan beberapa hal untuk menganalisis potensi sumber belajar. Analisis potensi sumber belajar yang meliputi kurikulum 2013 yang mengarahkan siswa dengan pendekatan ilmiah (scientifik approach), materi, dan tujuan pembelajaran. Arikunto (2013), dalam pekerjaan analisis dapat meliputi 3 langkah sebagai berikut: 1) Persiapan, 2) Tabulasi Analisis Data Produk, 3) Penerapan. Bahan ajar ini kemudian dilakukan pengujian validasi sehingga mendapatkan bahan pembelajaran yang layak. Sumber belajar yang dibuat dari penelitian ini berbentuk poster berbasis potensi lokal yang divalidasi oleh ahli Materi dengan tingkat kevalidan $81,25 \%$, ahli desain $96,88 \%$ dan guru biologi 86,71,\%, sehingga hasil presentase penilaian dari ketiga validator tersebut sebesar $87,98 \%$,diperolehsekor rata-rata sebesar $81,3 \%$ sehingga hasil penelitian yang dibuat sebagai bahan ajar poster dapat digunakan dengan kreteria baik dan hasil penelitian ini dapat dijadikan sumber belajar dimasyarakat

\section{KESIMPULAN}

Pengaruh variasi pengolahan daun dan buah kacang panjang terhadap kadar Timbal $(\mathrm{Pb})$ dan
Cadmium (Cd) yaitu adanya Pengaruh variasi pencucian dan pemasakan terhadap penurunan kadar logam berat timbal $(\mathrm{Pb})$ dan cadmium $(\mathrm{Cd})$ pada bagian daun dan buah.

Pengolahan yang lebih efektif mengurangi kadar logam berat Timbal $(\mathrm{Pb})$ dan Cadmium $(\mathrm{Cd})$ pada daun dan buah kacang panjang serta sosialisasi penanganan sayuran tercemar yaitu adanya Pengaruh variasi pencucian sebanyak 3 kali pencucian. dan pemasakan terbaik terhadap penurunan kadar logam berat timbal $(\mathrm{Pb})$ dan cadmium (Cd) pada bagian daun dan buah kacang panjang yaitu dengan cara ditumis pada daun $\mathrm{Pb}$ sebesar 12,39 $\mathrm{mg} / \mathrm{kg}$ dan Cd 13,68 mg/kg, pada buah sebesar 6,69 mg/kg dan Cd 11,05 $\mathrm{mg} / \mathrm{kg}$. Pemasakan dengan cara ditumis.

Variasi kadar logam berat dari hasil penelitian pengolahan daun dan buah kacang panjang terhadap kadar Timbal ( $\mathrm{Pb})$ dan Cadmium (Cd) sebagai sosialisasi penanganan sayuran tercemaryaitu tidak adanya interaksi variasi pencucian dan pemasakan terhadap penurunan kadar logam berat timbal $(\mathrm{Pb})$ dan cadmium $(\mathrm{Cd})$ pada bagian daun dan buah dikerenakan nilai signifikan lebih besar dibandingkan nilai 0,05 yaitu sebesar 0,371 Pencucian terbaik menurunkan kadar logam berat timbal $(\mathrm{Pb})$ dan Cadmium (Cd) pada bagian daun dan buah kacang panjang yaitu sebanyak 3 kali selama 15 detik. Tidak ada perbedaan variasi pencucian dan pemasakan terbaik menurunkan kadar logam berat timbal $(\mathrm{Pb})$ dan Cadmium (Cd) pada bagian daun dan buah kacang panjang dan media pembelajaran dimasyarakat berupa 
poster dengan kretria kelayakan sebesar $81,3 \%$ berupa poster Penanganan sayuran tercemar di masyarakat dengan kreteria baik.

\section{SARAN}

Saran yang dapat diajukan dalam penelitian selanjutnya antara lain adalah dalam dunia pendidikan hendaknya guru dan pendidik pada umumnya menggunakan potensi lokal dalam pembelajaran mengolah sayuran khususnya kacang panjang agar terhindar dari logam berat berbahaya seperti $\mathrm{Pb}$ dan $\mathrm{Cd}$. Penelitian ini hanya terbatas mencari cara pengolahan dengan pencucian dan pemasakan yang paling efektif dalam mengurangi kadar logam berat $\mathrm{Pb}$ dan $\mathrm{Cd}$ tetapi kurang memperhatikan nilai gizinya, oleh karena itu alangkah baiknya pada penelitian selanjutnya menganalisis nilai gizinya.. Produk yang dibuat berupa Poster, akan tetapi pada penelitian ini hanya pada tingkat validasi ahli, belum sampai pada tingkat uji coba, untuk penelitian selanjutnya dapat meneruskan penelitian dalam penggunaan poster untuk diuji dalam penerapan masyarakat dan perlu kajian yang lebih mendalam.

\section{DAFTAR RUJUKAN}

Aisyah, Yuliani, Rasdiansyah, Muhaimin, 2014. Pengaruh Pemanasan terhadap Aktivitas Antioksidan pada Beberapa Jenis Sayuran. Jurnal Teknologi dan Industri Pertanian Indonesia. Vol.06, No.02. Aceh.Jurusan Teknologi Hasil Pertanian, Universitas Syiah Kuala.
Arikunto, S. 2013. Prosedur Penelitian Suatu Pendekatan Praktik. Jakarta: Rineka Cipta.

Bastianus, Z. Marisi Napitupulu, dan Puji Astuti. 2014. Respon Tanaman Kacang Panjang (Vigna Sinensis L.) terhadap Pemberian Pupuk Npk Pelangi dan Pupuk Organik Cair Nasa. Jurnal Agrifor Volume Xiii Nomor 1, Maret 2014. ISSN: 1412 -6885. Agroteknologi, Fakultas Pertanian, Universitas 17 Agustus 1945 Samarinda, Indonesia.

Budiari, A. D. T., Lani, I. G. A. Triani, A. Hartiati. 2015. Pengaruh Frekuensi Pencelupan dan Lama Perebusan terhadap Kadar Logam Berat dan Mutu Sensoris Sawi Hijau (Brassica rapa I. Subsp. Perviridis Bayley). Jurusan Teknologi Industri Pertanian Fakultas Teknologi Pertanian UNUD.

Charlena. 2004. Pencemaran Logam Berat Timbal $(\mathrm{Pb})$ dan Cadmium (Cd) pada Sayursayuran. Bogor. Program Pascasarjana/S3/ Institut Pertanian Bogor Ditjen Cipta Karya. 2003. Profil Kota Metro. Kota Metro.

Fachrul, \& Ferianita, M. 2007. Metode Sampling Bioekologi. Jakarta: Bumi Aksara.

Fardiaz, S., 1992, Mikrobiologi Pangan I.Jakarta:PT Gramedia Pustaka Utama.

Gussarsson M. 1994. Cadmiuminduced Alterations in Nutrient Composition and Growth of Betula Pendula Seedlings: The Significance of Fine Root as a 
Primary Target for Cadmium

Toxicity. Journal of Plant

Nutrition 17, 2151-63.

Haryanto, E., Suhartini T., \& Rahayu

E. 2007. Budidaya Kacang

Panjang. Penebar Swadaya.

Jakarta

Hutapea, J. R. 1994. Inventaris

Tanaman Obat Indonesia III,

Badan Penelitian dan

Pengembangan Kesehatan,

Jakarta.

Jeliazko, V. D. 2001. Study on Heavy

Metals Absorption by Plants.

University of Massachusetts

Amherst. http://www.lib.umicom/dissertation/fullcit.

Diakses tanggal 27 Juni 2014.

Karwono, \& Mularsih, H. 2010.

Belajar dan Pembelajaran serta

Pemanfaatan Sumber Belajar.

Ciputat: Cerdas Jaya.

Sujarwanta, A. 2012. Mengkondisikan

Pembelajaran Ipa Dengan

Pendekatan Saintifik (Natural

Science Learning Conditional

with Saintific Approach).
Jurnal Nuansa Kependidikan

Vol 16 Nomor.1, Nopember 2012.

Widowati, H., Sulistiani, W. S. \& Sutanto, A. 2017. Pengaruh Proses Pengolahan terhadap Kadar Logam Berat dan Kadar Gizi Pada Kacang Panjang. Bioedukasi Vol 8. No 2 Nov 2017.

Widowati, H. 2011. Logam Berat $\mathrm{Cd}, \mathrm{Pb}$ terhadap Perubahan Warna Batang dan Daun Sayuran". El-Hayah. Vol. 1, No.4 Maret 2011. 167-173.

Widyantari, I. G. Lani Triani, A. \& Gunam, I. B. 2015. Pengaruh Perlakuan Pencucian dan Perebusan terhadap Kadar Residu Insektisida dan Karakteristik Sensoris Pada Sayuran Kembang Kol (Brassica oleracea var.botrytis L). Jurusan Teknologi Industri Pertanian: Fakultas Teknologi Pertanian Unud. 